\title{
Past and present distribution of Myxas glutinosa (O.F. Müller, 1774) in the waterbodies of the Urals and Siberia
}

\author{
Maxim V. VINARSKI, ${ }^{1 *}$ Maxim E. GREBENNIKOV, ${ }^{2}$ Olga S. SHISHKOEDOVA ${ }^{3}$ \\ ${ }^{1}$ Museum of Siberian Aquatic Mollusks, Omsk State Pedagogical University, Omsk; ${ }^{2}$ Zoological Museum of the Institute of Plant and \\ Animal Ecology of the Russian Academy of Sciences, Yekaterinburg; ${ }^{3}$ Omsk State Pedagogical University, Omsk, Russian Federation \\ *Corresponding author: radix.vinarski@gmail.com
}

\begin{abstract}
The distribution of the glutinous snail, Myxas glutinosa (O.F. Müller, 1774), in the waterbodies of the Urals and Western Siberia has been assessed on the basis of the literary and authors' own data. This species belongs to the rarest among the Euro-Siberian freshwater snails, and the Ural-Siberian region is the eastern part of its range. The first records of $\mathrm{M}$. glutinosa in this area date back to 1889 but to the date only 48 trustworthy findings of the species in this region are known. The map of these findings is provided. Currently, M. glutinosa is extremely rare in Siberia though in the South Uralian waterbodies its abundance is still relatively high. Possible causes of decline of the glutinous snail are briefly discussed. It is shown that this species may tolerate (to some extent) water pollution, salinity and other factors that were invoked to explain its global decline.
\end{abstract}

Key words: Myxas glutinosa, Siberia, Urals, rarity, distribution, snails.

Received: December 2012. Accepted: February 2013.

\section{INTRODUCTION}

The glutinous snail, Myxas glutinosa (O.F. Müller, 1774), is usually mentioned among the rarest species of European freshwater pulmonate mollusks. The species' range is relatively wide and covers much of Europe and Western Siberia (Glöer, 2002; Kruglov, 2005). The abundance of this snail has declined drastically in many European countries during last century and the number of waterbodies inhabited by the glutinous snails has decreased as well (Bouchet et al., 1999). For example, it became extremely rare in Great Britain. Killeen (1992) states that $M$. glutinosa seems to have virtually disappeared in Britain, although several findings during 19601990s are known (Kerney, 1999). As one can judge from the Kerney (1999), Holyoak (2005), and Beckmann (2006), the glutinous snails are still to be found in Ireland, and it is estimated that Ireland maintains up to $50 \%$ of the global population of M. glutinosa (Byrne et al., 2009). It has an endangered (EN) status in this country (Byrne et al., 2009). In the Netherlands, there is a relatively large amount of sites where $M$. glutinosa has recently been recorded (Gittenberger et al., 1998; de Bruyne et al., 2008), however, it is extremely rare in Germany (P. Glöer, personal communication) and in the Czech Republic (Beran, 2002; M. Novak, personal communication). Only several localities of this species are mentioned in papers devoted to the malacofauna of the Scandinavian countries (Økland, 1990; Nilsson et al., 1998). In Poland, the species is so rare now that even Dr. Jackiewicz, a promi- nent expert in lymnaeid taxonomy, has never found living specimens in this country (Szarowska and Falniowski, 2006). It is often assumed that $M$. glutinosa became an EN species throughout its range and, possibly, is driven to extinction (Bouchet et al., 1999; Carlsson, 2000; Vinarski, 2008). This situation is comparable to other examples of globally declining freshwater species, for example, to the case of global decline of Aegagropila linnaei (lake ball), a species of freshwater green algae (Boedeker et al., 2010).

As a result, the glutinous snail is currently under protection in many European states and it is inscribed now in different lists of threatened species, including the International Union for Conservation of Nature (IUCN) Red List, ESC Red List, Coordination of information on the environment (CORINE) programme, and Bern Convention (Baillie and Groombridge, 1996; Whitfield et al., 1998; Hubenov, 2007).

Surprisingly, this species has been assessed recently as belonging to least concern (LC) category in the European Red List of Non-marine mollusks (Cuttelod et al., 2011). This fact is difficult to explain given a drastic decline of M. glutinosa throughout Europe and its presence in Red Lists of many European countries. Possibly, it reflects our poor knowledge of this species abundance throughout its range, including the eastern part of it covering the former USSR area.

The information about the current distribution and abundance of M. glutinosa in the countries of the former USSR is more than scarce since most authors dealing with 
the glutinous snail (Leshko, 1998; Stadnichenko, 2004; Kruglov, 2005) do not discuss its abundance and potential conservation status. The article by Zettler et al. (2005) is a good exception as the authors reported some recent findings of the species in the Baltic country (Lithuania) and concluded that M. glutinosa scheint in Litauen noch relativ gute Lebensbedingungen vorzufinden (i.e. it appears that this species find relatively good life conditions in Lithuania, our translation).

Thus, the glutinous snail should be considered as the subject of serious attitude from the malacologists and conservation managers. Its current abundance and geographic distribution in the easternmost part of the species' range, i.e. in Siberia and adjacent parts of the Urals seem worthy of attention. The report on the authors' decennial (20002012) field samplings and museum studies on M. glutinosa is presented below.

\section{METHODS}

The data on the current distribution of the glutinous snail have been collected during authors' long-term field studies of mollusks in freshwater communities of the Urals and Western Siberia. The samplings were made along the standard methods (Zhadin, 1960; Glöer, 2002). The authors' collections are housed in two scientific institutions: i) the Zoological Museum of the Institute of Plant and Animal Ecology [Uralian branch of the Russian Academy of Sciences (IPAE), Yekaterinburg]; and ii) the Museum of Siberian Aquatic Mollusks, Omsk State Pedagogical University (MSAM). Mollusks sampled in 2010 are kept in the O. Shishkoedova private collection, Chelyabinsk.

In order to understand whether the abundance and distribution range of $M$. glutinosa have changed during the $20^{\text {th }}$ century, we created a database containing all reliable recordings of the species from the waterbodies of the Urals and Western Siberia. This database embraces findings from the 1880s and includes all available information from literary sources as well as data on museum samplings made between 1920 and 2012. The collections of the Zoological Institute of the Russian Academy of Sciences (ZIN) - Saint-Petersburg, the Research Institute of Biology and Biophysics - Tomsk, and the IPAE were examined for this purpose. Though many authors did not supply their checklists and reports with pictures of shells or snails descriptions, we are inclined to believe that some morphological peculiarities of this snail (especially its very thin translucent shell alongside with almost non-visible spire and mantle covering the shell while alive) make M. glutinosa rather easy to identify. There is no other lymnaeid species in the Ural-Siberian region that could be confused with the latter, therefore we decided to account even those distributional data that are not confirmed by museum specimens.

The taxonomic identification of the snails was carried out by using keys published by Jackiewicz (1998), Glöer (2002), Stadnichenko (2004), and Kruglov (2005).

\section{RESULTS}

According to our database, 48 localities of $M$. glutinosa were discovered in the Urals and Western Siberia since 1889. Most of them are situated in the Uralian waterbodies (Fig. 1).

\section{Past and present distribution of the glutinous snail in the Uralian waterbodies}

The first author to record M. glutinosa from the Uralian waterbodies was Boettger (1890), who found this species in the malacological collection of A.M. Khlebnikov sampled in vicinities of Kungur town (now Perm' region). Other recordings of the glutinous snails from the region are those by Vorontsovsky (1922), Zvereva (1969), Zatravkin (1980), and Leshko $(1983,1998)$. Besides, many samples collected in 1906-1963 were found in the ZIN and IPAE collections. Our special investigations in the waterbodies of Middle and South Urals carried out in 2007-2012 brought 13 new localities of M. glutinosa. Thus, the species seems to be not too rare in large lakes of the South Urals. However, the abundance of the snails in the Uralian lakes is not high and never exceeds 7-8 specimens per $\mathrm{m}^{2}$.

The Pechora river basin is another region where the species is possibly more or less common. M. glutinosa has repeatedly been registered there since 1905 (A. Zhuravsky collection, ZIN). Most findings of the glutinous snail in the Pechora basin were made in 1950-1970 and these are summed up by Leshko (1998). Unfortunately, no information about the current state of M. glutinosa in this region is available.

\section{Past and present distribution of the glutinous snail in Siberia}

M. glutinosa probably was the rarest species in Siberia long ago, at least since the 1920 s. Its first record in Western Siberia is that of Johansen (1934), who mentioned this snail from neighborhood of Tomsk city. No data on the abundance of M. glutinosa, though, were given in this publication. Mozley (1936), who made an extensive study of Siberian freshwater mollusks in 1932-1933, was not able to find at least one specimen of M. glutinosa and quoted only Johansen's record in his checklist.

In 1960-1970s, the waterbodies of Siberia was investigated extensively by malacologists, but $M$. glutinosa was usually considered as a rare species. Its scarcity in collections was reported by Lazareva (1968), Novikov (1971), Frolova (1973), and other authors. For example, Novikov (1971), who studied the freshwater malacofauna of the middle $\mathrm{Ob}$ ' basin, collected altogether nearly 7000 spec- 
imens of mollusks in 600 samples, but only three individuals of M. glutinosa were found in these samples. In 19551961, Drozdov $(1963,1965)$ investigated the malacofauna of the Irtysh basin. More than 500 samples of freshwater mollusks were gathered but only two localities of M. glutinosa were registered. According to the data of Lazareva (1968) and Frolova (1973), M. glutinosa was very scarce in the north Kazakhstan area in the late 1960s (only three localities were found by each author). Blagovidova (1969) reports that the species was presented in the malacofauna of the Novosibirsk reservoir in 1956-1961, but more recent findings of it in this large body of water are not known.

In the Yenisei basin, which is situated in Central Siberia, the only record of the glutinous snail is registered to date. Gundrizer (1979) discovered the species in one waterbody lying close to the Polar circle, in the floodplain of the lower part of the Kurejka river (point 4 in Fig. 1). This locality is surely the northernmost one in the Asiatic part of the species range. Another finding of M. glutinosa from the eastern part of the Yenisei basin published in 1999 (Prozorova and Sharyi-Ool, 1999), was based on misidentification (Zasypkina, 2011).

The conclusions of the malacologists mentioned above are corroborated by our own data. Since 2000 , more than 550 waterbodies of Western Siberia were investigated by the authors' team and to date we can report only two findings of M. glutinosa in the region (Fig. 1), namely: i) 22.10.2002. Kazakhstan, Kustanay region, Sary-Kopa basin, Ulkendamdy river $\left(51^{\circ} 09^{\prime} 51.8^{\prime \prime} \mathrm{N}, 65^{\circ} 01^{\prime} 12.4^{\prime \prime}\right.$ E; point 1 in Fig. 1). (Collected by M.V. Vinarski). Five living specimens were dredged from the shore slope of a small steppe river alongside with numerous Valvata spp. and Sphaerium spp. No anatomical differences from the European glutinous snails (Jackiewicz, 1998; Kruglov, 2005) were revealed; ii) 09.08.2006. Russia, Tomsk region, vicinity of Tomsk city, Mochishche oxbow lake near Vershinino village $\left(51^{\circ} 14^{\prime} \mathrm{N}, 84^{\circ} 55^{\prime} \mathrm{E}\right.$; point 2 in Fig. 1). (Collected by M.V. Vinarski and A.V. Karimov). More than 50 juvenile individuals were sampled from the candock (Nuphar lutea L.) leaves. The molluscan assemblage of this lake includes Lymnaea fragilis (L., 1758) $(=$ L. stagnalis auct.), Radix auricularia (L., 1758), R. balthica (L., 1758), Acroloxus lacustris (L., 1758), Physa adversa Da Costa, 1778 (=Physa fontinalis auct.), and Anisus vortex (L., 1758).

The southern border of the glutinous snail range in Siberia lies somewhere in Central Kazakhstan. Recently,

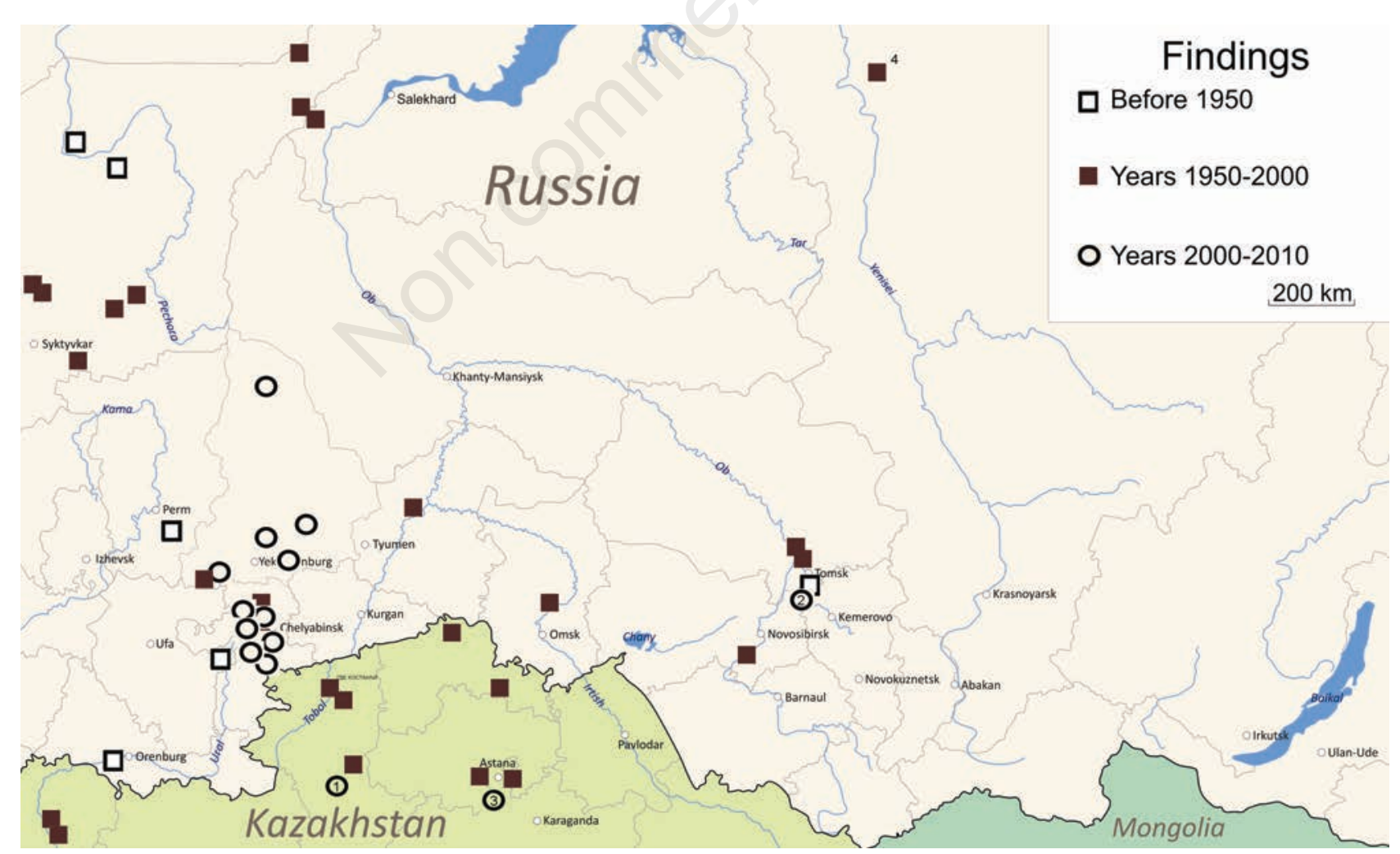

Fig. 1. Findings of M. glutinosa in the Urals and Siberia. Numbers 1-4 correspond to some remarkable findings of the species in Siberia (see text). 
one more finding of $M$. glutinosa was reported from the Kulanutpes river (point 3 in Fig. 1) belonging to the Nura drainage basin (Krainyuk, 2012).

\section{Summary}

In the Urals and Western Siberia, M. glutinosa typically prefers permanent waterbodies such as large or mediumsized lakes (including oxbow lakes), reservoirs, and small rivers with slow current (Fig. 2). Records of this snail from temporary habitats and smaller permanent lakes and ponds are absent in this region. Sometimes, M. glutinosa may be recorded in waterbodies situated in industrial and heavily populated landscapes. For example, in September of 2009 several living specimens of mollusks were found by O. Shishkoedova in the Miass river in Chelyabinsk city (Southern Urals, Russia). The snails showed no signs of abnormality or depressed development (Fig. 3), though their habitat is situated in a close proximity to an industrial plant (Fig. 4). The Miass river is heavily polluted by numerous anthropogenic sources, thus M. glutinosa are potentially able to tolerate chemical pollution of the aquatic environment. However, the extent of such tolerancy should be studied in the future.

\section{DISCUSSION}

The records and distribution data given above evidence that $M$. glutinosa is generally infrequent and not abundant

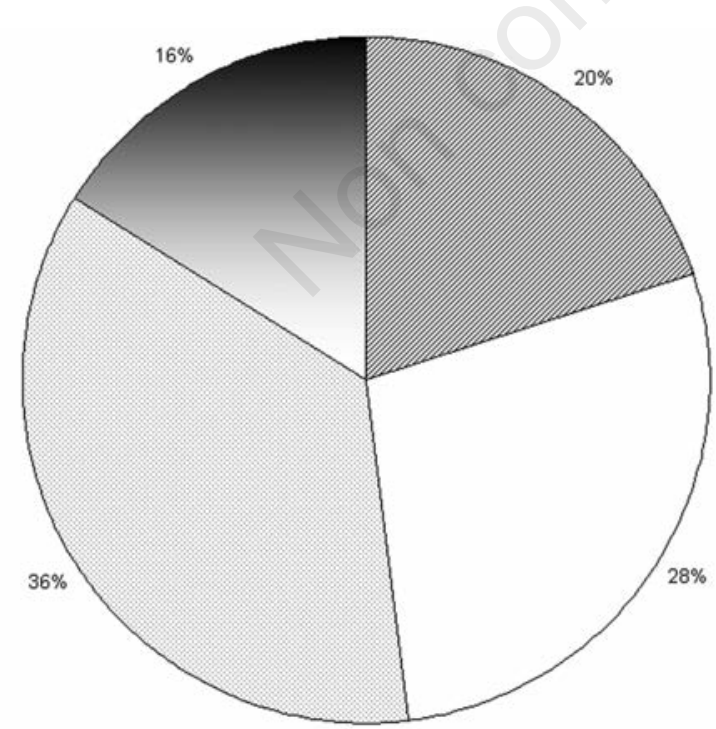

\begin{tabular}{|ll|}
\hline$\square$ Rivers & $\square$ Oxbow lakes \\
$\square$ Large lakes & $\square$ Reservoirs \\
\hline
\end{tabular}

Fig. 2. Habitat preferences (in percents) of M. glutinosa in the Uralian and Western Siberian waterbodies. in the eastern part of this range. This fact is especially clear from the study of the species distribution in Siberia, where it was always very rare. We can report an obvious decline of M. glutinosa in Northern and Central Kazakhstan (south part of the western Siberian plain), where in 2002-2012 only three localities of the glutinous snail were discovered, while in the 1960s the distribution of this species was not so sporadic (Lazareva, 1968; Frolova, 1973). The recent faunistic information collected in the Middle and South Urals allow us to suppose that the glutinous snail is still not very rare in this region and can be found in a range of waterbodies. Possibly, the Pechora river basin is the second area of relative abundance of $M$. glutinosa in the Urals.

The causes of global decline of the species are rather obscure. There is no common agreement among researchers on some important points of the species ecology and sometimes contradictory statements are issued. Many researchers have reported data on the low tolerance of $M$. glutinosa to different environmental factors. For example, it is registered to be susceptible to biodegradable pollution (Mouthon and Charvet, 1999) and sensitive to eutrophication (Whitfiled et al., 1998; Donohue et al., 2009) as well as to high degree of the water's hardness (Beriozkina et al., 1980). Zhadin (1952), on the contrary, believes $M$. glutinosa to inhabit distrophic lakes and oxygen deficient waterbodies. Carlsson (2001) and Briers (2003) mentioned the species among calcephile mollusks that do not

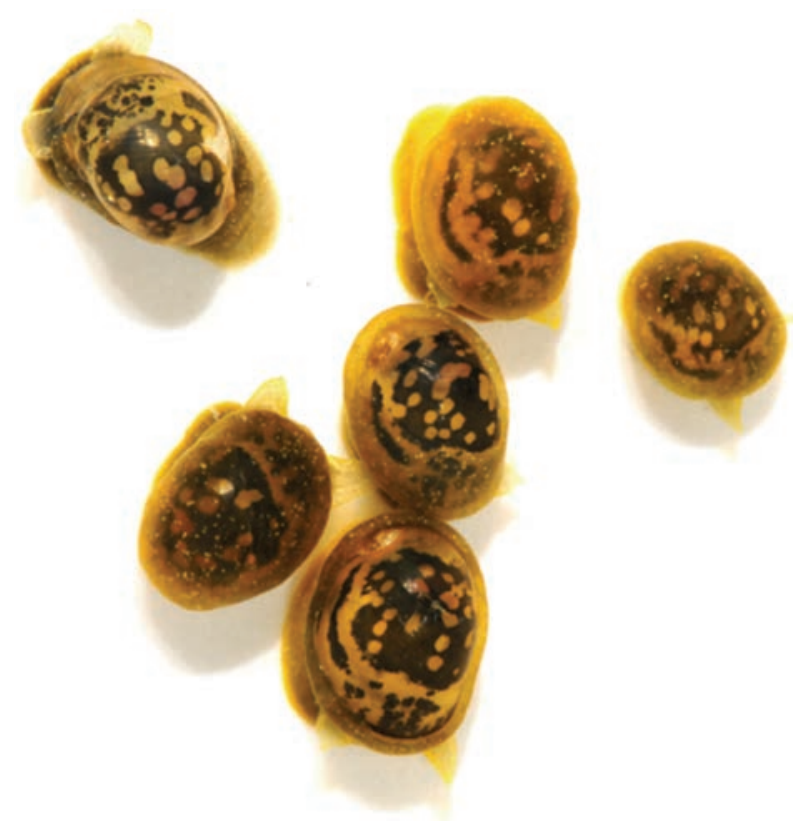

Fig. 3. Living specimens of M. glutinosa from the Miass river (Chelyabinsk City, 16.09.2009, leg. O.S. Shishkoedova). The shell of the largest snail is $11.5 \mathrm{~mm}$ height. 


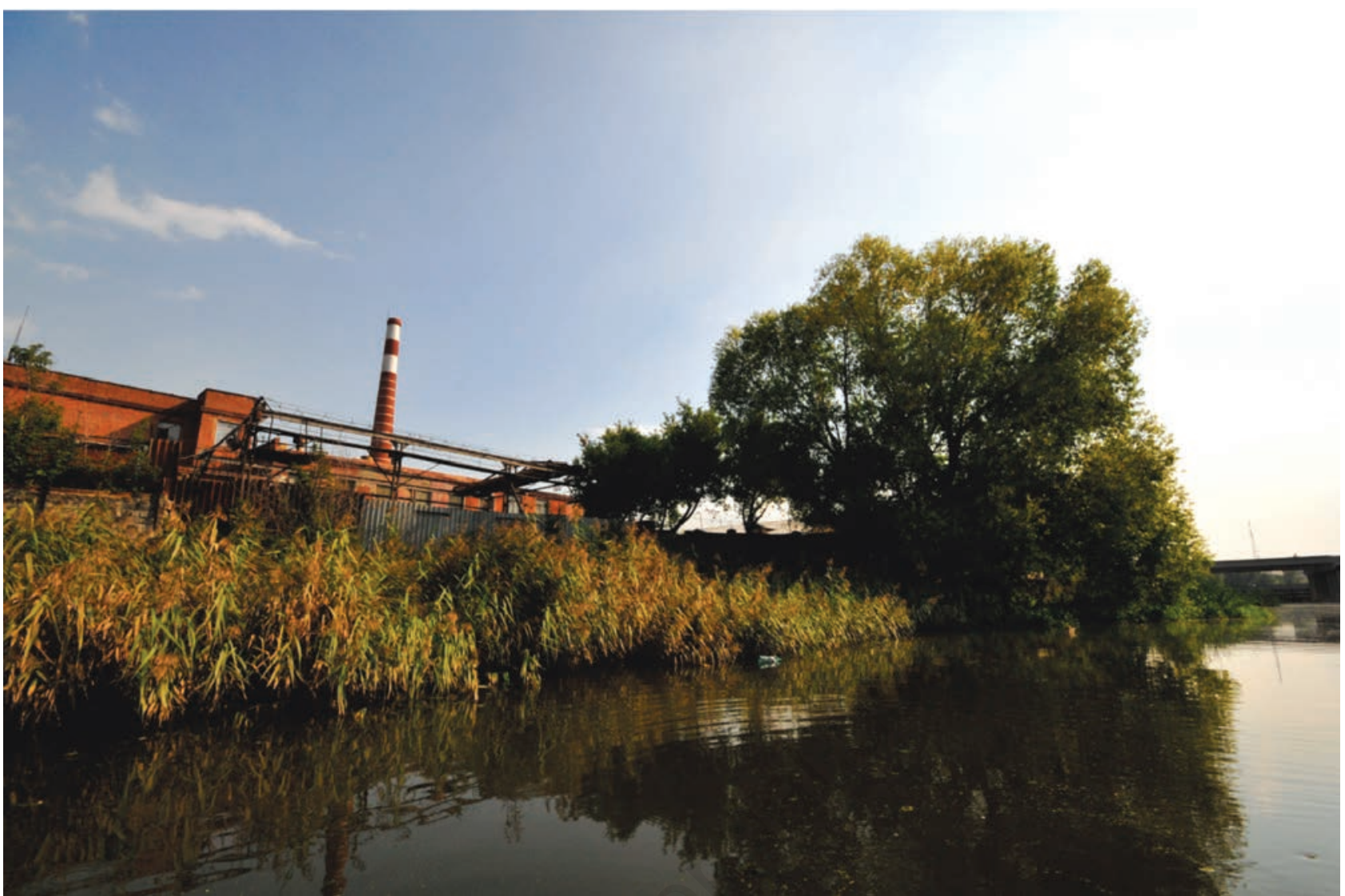

Fig. 4. The view of the habitat of M. glutinosa in Chelyabinsk City (Miass river).

inhabit calcium-deficient waterbodies. Moreover, $M$. glutinosa is not tolerant to low values of ambient $\mathrm{pH}$ (Salazkin, 1969; Berezina, 2001).

Some of these alleged causes of decline can however be ruled out. Namely, the lymnaeid species Lymnaea ovata (Drapanaud, 1805) [=Radix balthica (L., 1758)] that is not considered to be rare has equalled M. glutinosa's range of $\mathrm{pH}$ tolerance, 6.0-9.0 (Berezina, 2001). According to our data collected in June 2010, the water salinity also does not limit the glutinous snail distribution. In the South Urals it inhabits waterbodies where salinity varies from 90 to 593 ppm. Furthermore, Carlsson (2000) found M. glutinosa in eutrophic habitats in the Alland islands, therefore its alleged intolerance to eutrophication (Whitfiled et al., 1998) may be questioned. Recent finding of M. glutinosa in a polluted area of a large industrial city (see Results section) affirms that this species is not critically dependent on the purity of water.

\section{CONCLUSIONS}

At last, it is possible that rarity of $M$. glutinosa is partially explained by some peculiarities of its life cycle. Fe- liksiak (1939) reported that this species lives only one year (until spring) and in the summer season only juvenile individuals occur. Due to their small size, the juveniles can be overlooked by collectors to give the impression of absence of this species in a waterbody. Special efforts are needed to learn if this assumption is true.

\section{ACKNOWLEDGMENTS}

The authors wish to thank Prof. V.N. Drozdov (Omsk, Russia), who kindly provided us with the manuscript containing the ecological and faunistic data on freshwater mollusks inhabiting the Irtysh valley. Remarks of two anonymous reviewers helped us to improve the text. The financial support for the study was obtained partially from the Russian Fund for Basic Research (grant No. 12-0498056-p_sibir_a).

\section{REFERENCES}

Baillie J, Groombridge B, 1996. IUCN Red List of threatened animals. IUCN ed., Gland: 370 pp.

Beckmann K-H, 2006. [Die Mantelschnecke Myxas glutinosa (O.F. Müller 1774) in Irland (Gastropoda: Basommatophora: Lymnaeidae)]. [Article in German]. Heldia 6:221-223. 
Beran L, 2002. [Water shellfish in Czech Republic - spread and its variation, site, distribution, conservation threats, red list]. [Book in Czech]. Naturalists' club in Uherské Hradiště Publ., Uherské Hradiště: 258 pp.

Berezina NA, 2001. Influence of ambient $\mathrm{pH}$ on freshwater invertebrates under experimental conditions. Russ. J. Ecol. 32:343-351.

Beriozkina GV, Izakeinaite AP, Kiseleva LN, Konstantinova TS, 1980. [Some peculiarities of calcium content in shells of lymnaeid snails], p. 45-49. In: A.V. Andrievskiy (ed.), [Ecology of animals of Smolensk Region and adjacent areas]. [Book in Russian]. Smolensk State Pedagogical Institute Press.

Blagovidova LA, 1969. [Zoobenthos of the Novosibirsk Reservoir], p. 139-156. In: A.N. Petkevich (ed.), [Fish industry in waterbodies of the southern part of Western Siberia]. [Book in Russian]. Zapadno-Sibirskoe Book Publ.

Boedeker Ch, Eggert A, Immers A, Smets E, 2010. Global decline of and threats to Aegagropila linnaei, with special reference to the lake ball habit. Bioscience 60:187-198.

Boettger O, 1890. [Zur Mollusken-Fauna des russischen Gouvernements Perm und der Gebirge südöstlich von Orenburg. II]. [Article in German]. Separat-Abdruck aus Nachrichtsblatt der deutschen malacozoologischen Gesellschaft 22:161-173.

Bouchet P, Falkner G, Seddon M, 1999. Lists of protected land and freshwater molluscs in the Bern Convention and European Habitats Directive: are they relevant to conservation? Biol. Conserv. 90:21-31.

Briers RA, 2003. Range size and environmental calcium requirements of British freshwater gastropods. Glob. Ecol. Biogeogr. 12:47-51.

Byrne A, Moorkens EA, Anderson R, Killeen IJ, Regan EC, 2009. Ireland Red List No. 2. Non-marine molluscs. National Parks and Wildlife Service, Department of Environment, Heritage and Local Government Publ., Dublin: 49 pp.

Carlsson R, 2000. Ecology and lifecycle of Myxas glutinosa (Müller) in lakes of the Åland Islands, southwestern Finland. J. Conchol. 37:105-118.

Carlsson R, 2001. Freshwater snail communities and lake classification. An example from the Åland Islands, southwestern Finland. Limnologica 31:129-138.

Cuttelod A, Seddon M, Neubert E, 2011. European Red List of non-marine molluscs. Publication Office of the European Union, Luxembourg: 60 pp.

de Bruyne RH, Gmelig Meyling AW, Boesveld A, 2008. [Kleverige poelslak Myxas glutinosa Draparnaud, 1805], p. 116120. In: W. Kalkman (ed.), [The kinds of the environmental politics]. [Book in Dutch]. EIS Nederland Publ.

Donohue I, Donohue LA, Ainin BN, Irvine K, 2009. Assessment of eutrophication pressure on lakes using littoral invertebrates. Hydrobiology 633:105-122.

Drozdov VN, 1963. [Characteristics of malacofauna of rivers Tara and Shish as well as other small rivers and adjacent areas of the southern part of the Ob'-Irtyshian basin]. [Article in Russian]. Trudy Omskogo meditsinskogo instituta 37:143-150.

Drozdov VN, 1965. [The faunistic account of freshwater molluscs of the lower courses of the Tobol anf Tavda Rivers]. [Article in Russian]. Trudy Omskogo meditsinskogo instituta 61:51-55.
Feliksiak S, 1939. [Über Biologie und Morphologie der Mantelschnecke, Radix glutinosa (O.F. Müller, 1774)]. [Article in German]. Zool. Jahrb., Abt. Syst. Ökol. Geogr. Tiere 72:170.

Frolova ES, 1973. [Freshwater molluscs of the Northern Kazakhstan]. [Unpublished PhD Thesis in Russian]. Tomsk State University, Tomsk: 254 pp.

Gittenberger E, Janssen AW, Kuiper JGJ, Meijer T, Van der Velde G, De Fries JN, Peeters GA, 1998. [De Nederlandse Zoetwatermollusken. Recente en fossiele Weekdieren uit Zoet en Brak Water. Nederlandse Fauna. 2]. [Book in Dutch]. Nationaal Natuurhistorisch Museum Naturalis, KNNV Uitgeverij \& EIS-Nederland Publ., Leiden: 288 pp.

Glöer P, 2002. [Die Süßwassergastropoden Nord- und Mitteleuropas. Die Tierwelt Deutschlands]. [Book in German]. Conchbooks, Hackenheim: 327 pp.

Gundrizer VA, 1979. [Freshwater molluscs of the Lower Yenisei Basin]. [Unpublished PhD Thesis in Russian]. Tomsk State University, Tomsk: $214 \mathrm{pp}$.

Holyoak GA, 2005. New records of Myxas glutinosa and Catinella arenaria (Mollusca: Gastropoda) in Ireland. Irish Naturalists' Journal 28:175.

Hubenov Z, 2007. Fauna and zoogeography of marine, freshwater, and terrestrial mollusks (Mollusca) in Bulgaria, p. 141-198. In: V. Fet and A. Popov (eds.), Biogeography and ecology of Bulgaria. Springer Verlag.

Jackiewicz M, 1998. European species of the family Lymnaeidae (Gastropoda Pulmonata Basommatophora). Genus 9:193.

Johansen BG, 1934. The freshwater molluscs of Western Siberia. J. Mollus. Stud. 21:28-36.

Kerney M, 1999. Atlas of the land and freshwater molluscs of Britain and Ireland. Great Horkesley, Colchester: 254 pp.

Killeen I, 1992. The land and freshwater molluscs of Suffolk. Suffolk Naturalist's Society Publ., Ipswich: $171 \mathrm{pp}$.

Krainyuk VN, 2012. [A new finding of the glutinous snail Lymnaea glutinosa (L., 1758) in Central Kazakhstan], p. 125126. In: Proc. Int. Scient. Conf. [The Animal world of Kazakhstan and adjacent territories. Almaty, 22-23 Nov. 2012]. [Book in Russian].

Kruglov ND, 2005. [Lymnaeid snails of Europe and Northern Asia]. [Book in Russian]. Smolensk State Pedagogical University Press, Smolensk: 508 pp.

Lazareva AI, 1968. [Lymnaeid molluscs of the Kazakhstan]. [Unpublished PhD Thesis in Russian]. Zoological Institution of the Soviet Academy of Sciences, Leningrad: $161 \mathrm{pp}$.

Leshko YuV, 1983. [Freshwater molluscs of the Pechora basin]. [Book In Russian]. Nauka, Leningrad: 128 pp.

Leshko YuV, 1998. [Molluscs. Fauna of the North-East of European Russia]. [Book in Russian]. Nauka, Saint-Petersburg: $168 \mathrm{pp}$.

Mouthon J, Charvet S., 1999. Compared sensitivity of species, genera and families of Molluscs to biodegradable pollution. Ann. Limnol.-Int. J. Lim. 35:31-39.

Mozley A, 1936. The freshwater and terrestrial mollusca of Northern Asia. T. Roy. Soc. Edin.-Earth 58:605-695.

Nilsson C, Ericsson U, Medin M, Sundberg I, 1998. [Freshwater snails of southern Sweden as compared with the 1940s]. [Book in Swedish]. Swedish Environmental Control Rapport Publ., Stockholm: 77 pp. 
Novikov EA, 1971. [Freshwater molluscs of the Middle Ob' River basin]. [Unpublished $\mathrm{PhD}$ thesis in Russian]. Tomsk State University ed., Tomsk: 288 pp.

Økland J, 1990. Lakes and snails: environment and gastropoda in 1.500 Norwegian lakes, ponds and rivers. Universal Book Services/W. Backhuys Publ., Oegstgeest: 516 pp.

Prozorova LA, Sharyi-Ool MO, 1999. [Aquatic pulmonate molluscs (Gastropoda: Pulmonata) of Tuva]. [Article in Russian]. Bull. Russ. Far East Malac. Soc. 3:11-25.

Salazkin AA, 1969. [On certain peculiarities of gastropod distribution in different types of waterbodies of the humid zone of Western Siberia], p. 57-60. In: B.G. Johasen (ed.), [Problems of malacology in Siberia]. [Book in Russian]. Tomsk State University Press.

Stadnichenko AP, 2004. [Lymnaeidae and Acroloxidae of the Ukraine]. [Book in Russian]. Centr uchebnoj literatury Publ., Kiev: 327 pp.

Szarowska M, Falniowski A, 2006. Disappearance of freshwater gastropods in Niepołomice forest (South Poland). Tentacle 14:16-17.

Vinarski MV, 2008. Is the glutinous snail (Lymnaea glutinosa) driven to extinction? [Article in Russian]. Trudy Zoologicheskoi komissii Omskogo regional'nogo otdeleniya Russkogo Geograficheskogo Obschchestva 5:8-18.
Vorontsovsky PA, 1922. [Materials to the knowledge of molluscs of the vicinity of Orenburg]. [Article in Russian]. Trudy Obschchestva izucheniya Kirgizskogo kraya 3:31-39.

Whitfield M, Carlsson R, Biggs J, Walker D, Corfield A, Fox G, Williams P, 1998. The ecology and conservation of the glutinous snail Myxas glutinosa (Müller) in Great Britain: a review. J. Conchol. 2:209-221.

Zasypkina MO, 2011. [New data on lymnaeid snails of Tuva], p. 178-179. In: Buryat State University (ed.), [Diversity of soil and biota of the Northern and Central Asia]. [Book in Russian]. Buryat State University Press.

Zatravkin MN, 1980. [The hydromalacofauna of the Ilmeny reserve]. [Article in Russian]. Zool. Zh. 59:452-455.

Zettler M, Zettler A, Daunys D, 2005. [Bemerkenswerte Süßwassermollusken aus Litauen. Aufsammlungen vom September 2004]. Malak. Abh. 23:27-40.

Zhadin VI, 1952. [Fresh- and brakishwater mollusks of the USSR]. [Book in Russian]. Sovetskaya Nauka, Moscow: $346 \mathrm{pp}$.

Zhadin VI, 1960. [Methods of hydrobiological research]. [Book in Russian]. Vysschaya shkola, Moscow: $191 \mathrm{pp.}$

Zvereva OS, 1969. Biological peculiarities of the main rivers of Komi Autonomous Republic. [Book in Russian]. Nauka, Leningrad: 279 pp. 